\title{
IMPLEMENTASI SOFT SKILL TRAINING BAGI NARAPIDANA LAPAS CIAMIS
}

\author{
Hendi Budiaman ${ }^{1}$, Dewi Mulyanti ${ }^{1}$, Dendy Syaiful Akbar ${ }^{2 *}$ \\ ${ }^{1}$ Fakultas Hukum Universitas Galuh, Ciamis \\ ${ }^{2}$ Fakultas Ekonomi Universitas Galuh, Ciamis \\ *Email: dendysyaiful1984@gmail.com
}

\begin{abstract}
ABSTRAK
Khalayak sasaran yang menjadi mitra dalam kegiatan ini adalah masyarakat penghuni Lembaga Permasyarakatan Kls II B Ciamis yang memiliki waktu sekitar 1-3 bulan sebelum bebas. Permasalahan yang dialami oleh mitra adalah kurangnya pembinaan pengembangan diri dari para narapidana di Lapas Ciamis, sehingga menimbulkan kemungkinan rentannya narapidana terjerumus kembali kepada tindakan-tindakan yang melanggar hukum setelah keluar dari penjara karena himpitan ekonomi dan tidak memiliki bekal keterampilan dan pengetahuan yang cukup. Kegiatan-kegiatan yang telah dilaksanakan diantara nya adalah Tes Pra Kegiatan, dimana hasilnya menunjukan bahwa pengetahuan narapidana yang menjadi Mitra PKM-S mengenai Pendidikan Hukum dan Kewirausahaan masih rendah. Hal tersebut dapat dilihat dari skor rata-rata hasil Tes Pra Kegiatan yang diperoleh adalah sebesar 45. Sementara itu kegiatan pelatihan Soft Skill Pendidikan Hukum dan Kewirausahaan telah dilaksanakan. Selama kegiatan para peserta mengikuti dengan antusias, dibuktikan dengan komunikatif nya mereka selama kegiatan berlangsung. Mereka berkomunikasi dengan pemateri dari Tim PKM-S mengenai hal-hal apa saja yang mereka perlu tanyakan, baik seputar materi yang diberikan, ataupun hal lainnya yang dianggap penting bagi mereka. Hasil Tes Pasca Kegiatan menunjukan adanya peningkatan pengetahuan mereka, yang dibuktikan dengan skor rata-rata yang diperoleh adalah sebesar 80. Maka dari hasil kegiatan ini dapat disimpulkan bahwa kegiatan pelatihan soft skill memberikan pengalaman baru bagi bagi mereka, dan dapat dijadikan bekal untuk menjalani kehidupan sehari-hari setelah mereka bebas dari penjara. Melihat antusiasme para narapidana dalam kegiatan ini, maka pihak Lapas Kelas II B Ciamis hendaknya memperbanyak kegiatankegiatan yang tujuannya adalah untuk memberi bekal pengetahuan dan keterampilan bagi Narapidana, karena dapat berguna bagi mereka kelak setelah bebas dari penjara.
\end{abstract}

Kata kunci: soft skill training, narapidana, hukum, kewirausahaan

\section{PENDAHULUAN}

Penjara merupakan tempat terasing dan sangat tertutup sehingga banyak orang yang sangat penasaran dengan kehidupan di dalam penjara. Banyak yang beranggapan penjara adalah sarang mafia dan dihuni oleh penjahat yang konon katanya bertampang seram-seram, badan penuh tato, tubuhnya kekar dan indentik dengan kekerasan. Begitulah citra penjara yang digambarkan di media dan dalam kenyataannya berbeda. Orang-orang hanya tahu kehidupan penjara dari gambaran film atau cerita seram penjara.

Penjara adalah suatu masyarakat tertutup, suatu institusi total. Apa yang terjadi di dalam dinding penjara tidak dengan mudah dapat dipelajari oleh orang luar dan apa yang terjadi di dalam sel seringkali tidak diketahui oleh petugas. Kehidupan narapidana dalam penjara diyakini sebagai suatu kehidupan yang keras, dimana narapidana sering kali menjadi korban. Kekerasan tersebut antara lain berupa gangguan dari sesama narapidana seperti pemerasan, penganiayaan, tindakan brutal, prasangka, stres, dan aneka ketegangan dalam kehidupan penjara (Purnianti, 2004).

Kondisi tersebut menyebabkan banyaknya program yang dilakukan di dalam penjara, dengan tujuan untuk tetap menjaga kondusifitas kondisi di dalam penjara. Walaupun akan 
selalu terdapat ketidak sempurnaan operasionalisasi program yang dijalankan di dalam penjara, cukup menarik perhatian bahwa pada kurun waktu beberapa tahun ini banyak terjadi pelarian-pelarian yang dilakukan oleh para narapidana dari berbagai lembaga pemasyarakatan di Indonesia. Diasumsikan, jika program pembinaan di lembaga pemasyarakatan berjalan seperti yang diharapkan, maka narapidana dalam menjalani masa hukumannya akan lebih sabar dan tabah. Pada kenyataannya, terjadi pelarian yang dilakukan oleh para narapidana. Hal ini dimungkinkan karena ada sebab-sebab tertentu yang mendasari niat para narapidana untuk melakukan pelarian.

Lembaga Permasyarakatan Kelas II B Ciamis kini dihuni sebanyak 401 orang tahanan, dimana sebanyak 318 narapidana laki-laki dan sebanyak 83 adalah narapidana perempuan, dimana dari jumlah tersebut, narapidana kasus narkoba mendominasi Lapas Ciamis. Selain itu, Lapas Ciamis pun dihuni oleh narapidana yang terjerat kasus pencabulan, pencurian, penipuan, kekerasan dan kasus-kasus lainnya.

Seorang tahanan selalu dituntut untuk disiplin dalam melakukan banyak hal, mulai dari bangun tidur, piket, makan dan juga berolahraga. Hal ini menyebabkan para tahanan jadi lebih sehat meski untuk makan mereka hanya diberi lauk seadanya. Yang penting kenyang dan tidak memedulikan rasa dan kandungan gizinya. Keteraturan dan kedisiplinan ini membuat tubuh para tahanan jauh lebih sehat, selalu bergerak, bahkan berhenti melakukan hal-hal buruk seperti rokok dan minum alkohol. Selain itu, di penjara mereka juga dituntut untuk rajin beribadah sesuai dengan agama masing-masing. Awalnya mereka akan dipaksa, namun lambat laun mereka jadi terbiasa. Dampaknya, akan banyak tahanan yang melakukan kontemplasi diri atau perenungan tentang hal yang telah ia lakukan. Perlahan-lahan ia akan jadi pribadi yang jauh lebih baik saat keluar dari sel-sel mengerikan itu.

Narapidana pada hakikatnya adalah manusia yang kehilangan kemerdekaan, akan tetapi narapidana memiliki hak yang sama dalam mendapatkan pendidikan yang berkualitas. Narapidana juga dapat berperan dalam pertumbuhan ekonomi, baik itu di dalam lapas maupun setelah keluar dari lapas dalam artian selesai menjalani hukuman. Narapidana sebagai bagian dari warga Indonesia walaupun telah melanggar hukum namun masih memiliki hak yang sama dalam menikmati pendidikan yang bermutu atau berkualitas. Hal tersebut sesuai yang tercantum dalam Undang-undang Sistem Pendidikan Nasional No 20 Tahun 2003 pasal 5 ayat (1) yaitu "Setiap warga negara mempunyai hak yang sama untuk memperoleh pendidikan yang bermutu".

Pada kenyataannya pendidikan yang diperoleh narapidana di Lapas Ciamis dirasakan kurang oleh semua warga lapas tersebut. Program-program yang dijalankan di dalam lapas 
tidak fokus dan hanya bersifat kondisional saja, seperti program "Seharian Bersama Keluarga" pada saat ulang tahun Kemenkumham atau pendidikan keagamaan dalam bentuk "Pesantren Kilat" hanya pada saat bulan suci Ramadhan. Pendidikan yang diperoleh Narapidana di Lembaga Permasyarakatan dipandang dapat menjembatani terlaksananya proses pendidikan yang terhenti pada pendidikan formal. Kebutuhan warga binaan akan bekal pengetahuan, keterampilan, kecakapan hidup, dan sikap untuk mengembangkan diri, mengembangkan profesi, bekerja atau usaha mandiri, sehingga mereka memiliki bekal setelah keluar dari penajara dan tidak terjerumus lagi pada tindakan-tindakan yang melanggar hukum.

Hasil penelitian yang dilakukan oleh Lubis dan Marsilah (2012) menunjukkan bahwa sumber-sumber kebermaknaan hidup bagi narapidana adalah: 1) Adanya nilai-nilai kreatif (creative values) untuk dapat berkarya, bekerja, mencipta serta melaksanakan tugas dan kewajiban sebaik-baiknya; 2) Adanya nilai-nilai penghayatan (experiential values), yakni dengan cara memperoleh pengalaman tentang sesuatu atau seseorang yang bernilai bagi subjek; 3) Nilai-nilai bersikap (attitudinal values) atas hukuman seumur hidup yaitu subjek memilih sikap menerima kondisi tersebut sebagai tanggung jawab yang harus dijalani akibat perbuatannya dan berusaha menikmati kehidupan di penjara dengan menjadikan penjara sebagai tempat untuk belajar menjadi manusia yang lebih baik.

Adanya pendidikan bagi narapidana dengan program pembinaan keterampilan diharapkan nantinya dapat menjadi manusia yang berkualitas dan mampu berperan dalam pembangunan dan pertumbuhan ekonomi, sehingga hidup seorang narapidana menjadi bermakna dan mencapai kebahagiaan hidup seperti layaknya masyarakat lain. Menurut Frankl (dalam Bastaman, 2007) menyatakan bahwa setiap orang selalu mendambakan kebahagiaan dalam hidupnya tak terkecuali seorang narapidana yang ruang geraknya dibatasi oleh jeruji.

Tujuan dari kegiatan ini adalah untuk mengimplementasikan soft skill kepada Narapidana Lapas Ciamis. Mitra dalam kegiatan ini adalah Narapidana Lapas Ciamis yang memiliki waktu sekitar 1-3 bulan sebelum bebas. Pemilihan mitra tersebut dimaksudkan agar Narapidana yang hendak bebas memiliki bekal keterampilan setelah mereka keluar dari jeruji besi, sehingga tidak lagi berniat melakukan kejahatan atau perilaku-perilaku yang bertentangan dengan hukum.

\section{BAHAN DAN METODE}

Kegiatan PKM-S ini dilaksanakan di Lapas Kelas II B Ciamis yang diselenggarakan pada bulan September 2019. Kelompo sasaran adalah Narapidana Lapas Kelas II B Ciamis 
yang memiliki sisa masa tahanan 1-3 bulan. Langkah-langkah yang ditempuh dalam kegiatan PKM-S ini adalah sebagai berikut:

1. Tes Pra kegiatan

Tes pra kegiatan dilakukan untuk mengetahui pengetahuan Narapidana yang menjadi Mitra PKM-S mengenai hukum dan kewirausahaan sebelum dilakukannya kegiatan. Metode ujian digunakan melalui soal pilihan ganda mengenai hukum dan kewirausahaan.

2. Pelatihan Soft Skill Pendidikan Hukum

Pelatihan soft skill dengan materi pendidikan hukum dilakukan dengan metode ceramah dengan menggunakan bantuan alat LCD Projector untuk memberikan pengetahuan mengenai hukum dan akibat yang akan dialami jika melanggar hukum.

3. Pelatihan Soft Skill Kewirausahaan

Pelatihan soft skill dengan materi kewirausahaan dilakukan dengan metode ceramah dengan menggunakan bantuan alat LCD Projector untuk memberikan pengetahuan kewirausahaan dan meningkatkan motivasi Narapidana/Mitra untuk berwirausaha setelah bebas dari penjara.

4. Tes Pasca Kegiatan

Tes pasca kegiatan dilakukan untuk mengetahui pengetahuan Narapidana yang menjadi Mitra PKM-S mengenai hukum dan kewirausahaan sesudah dilakukannya kegiatan. Metode ujian digunakan melalui soal pilihan ganda mengenai hukum dan kewirausahaan.

5. Evaluasi Kegiatan

Evaluasi hasil kegiatan dilakukan dengan metode analisis hasil tes pra dan pasca kegiatan menggunakan uji beda (t-test). Hasil analisis menggambarkan perubahan pengetahuan Narapidana/Mitra mengenai hukum dan kewirausahaan.

6. Pemantauan Khusus Keberlanjutan

Kegiatan ini dilakukan menggunakan metode diskusi antara Tim PKM-S dengan Narapidana/Mitra untuk menghasilkan saran atau rekomendasi mengenai keluhan-keluhan atau permasalahan-permasalahan yang mungkin dihadapi setelah bebas dari penajara.

\section{HASIL DAN PEMBAHASAN}

Kegiatan PKM-S yang telah dilaksanakan sejauh ini telah berjalan sesuai yang direncanakan, dimana Tim PKM-S telah melaksanakan tahap koordinasi dengan Lapas Kelas IIB Ciamis pada hari Senin 12 Agustus 2019 dan diterima oleh Kasi Binadik dan Giatja Zaenal Arifin, Amd, IP., S.H. karena Kalapas sedang tidak berada di tempat. Pertemuan tersebut dilakukan untuk menindaklanjuti Surat Permohonan Izin Pelaksanaan Kegiatan yang 
sudah dikirimkan pihak Universitas malalui LPPM beberapa hari sebelumnya. Dari hasil pertemuan tersebut, pihak Lapas yang diwakili Zaenal memberikan informasi bahwa kegiatan PKM-S ini dapat dilaksanakan setelah bulan Agustus 2019. Menurut penuturan beliau, bahwa dari pada bulan tersebut akan dilakukan persiapan dan pelaksanaan acara menyambut Hari Kemerdekaan Republik Indonesia ke 74. Maka kegiatan PKM-S akan dilaksankan pada bulan September 2019.

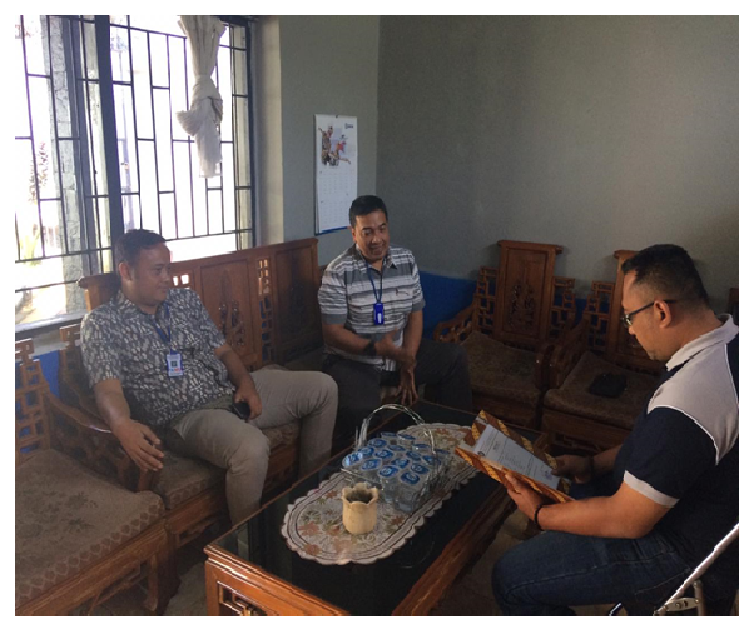

Gambar 1. Pertemuan dengan Pihak Lapas

Tepatnya pada hari selasa tanggal 9 September 2019 bertempat di Aula Lapas kelas IIB Ciamis Kegiatan PKM-S ini dilaksanakan, dimana kegiatan yang dilaksanakan adalah pelatihan soft skill dengan tema pendidikan hukum dan kewirausahaan. Pelatihan Life Skill ini diiukti oleh sebanyak 20 orang Narapidana. Menurut penuturan Sani Siti Aisyah, A.Md., IP., S.H., M.Krim. selaku Kasubsi Registrasi dan Bimkesmas Lapas Ciamis, selaku perwakilan dari Lapas Ciamis dalam kegiatan ini, menyebutkan bahwa kegiatan PKM-S ini sangat bermanfaat bagi Narapidana untuk mendapatkan pengalaman serta meningkatkan pengetahuan mengenai hukum dan kewirausahaan, dengan harapan para Narapidana memiliki bekal untuk melanjutkan kehidupan setelah bebas dari penjara, dan tidak terlibat kembali dengan perilaku yang melanggar hukum. Sani menuturkan bahwa kerjasama seperti ini perlu dilanjutkan setiap tahunnya, karena akan memberikan dampak positif bagi Narapidana.

Selama kegiatan berlangsung peserta menunjukan antusiasmenya, yang dibuktikan dari keaktipan para peserta untuk ikut membantu dalam tahap persiapan. Para peserta sangat komunikatif selama mengikuti kegiatan ini. Mereka banyak bertanya mengenai hal-hal yang merasa perlu untuk ditanyakan seputar materi atau hal lainnya. 


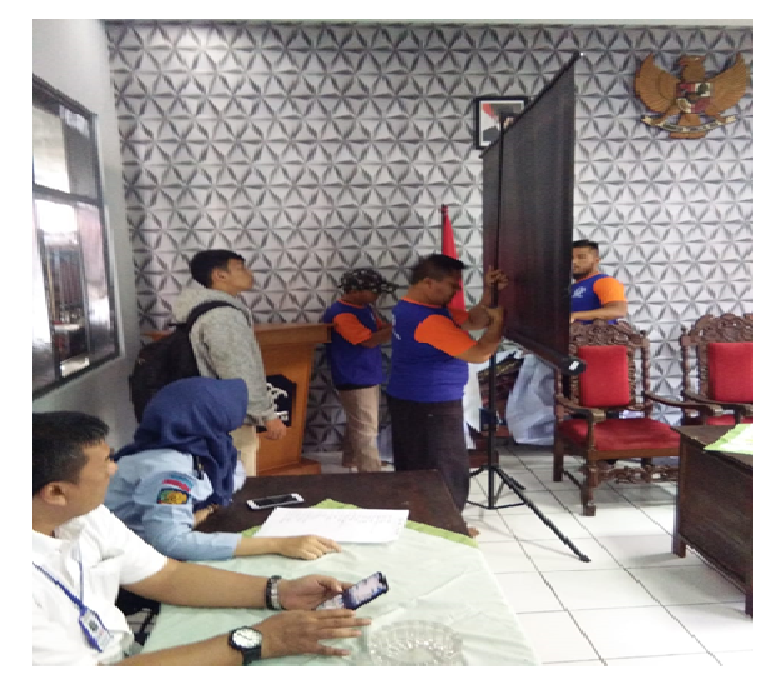

Gambar 2. Persiapan Kegiatan

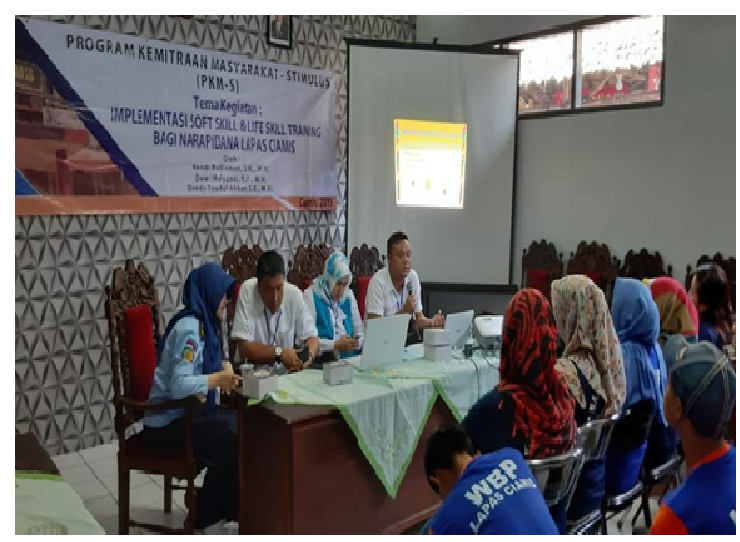

Gambar 3. Kegiatan Pelatihan Soft Skill

Selanjutnya hasil tes pra dan pasca kegiatan di analisis dengan menggunakan uji beda (t-test) dengan tingkat signifikansi sebesar 0,05 (sig =0,05). Analisis ini dilakukan untuk mengetahui perkembangan pemahaman peserta mengenai hukum dan kewirausahaan sebelum dan sesudah kegiatan dilaksanakan. Berikut adalah hasil uji beda ( $t$-test) menggunakan SPSS:

\section{Tabel 1. Hasil Uji Beda (t-test)}

\begin{tabular}{ccccc}
\hline Pengetahuan & N & Mean & SD & Sig \\
\hline Sebelum & 20 & 45,00 & 8,65 & 0,008 \\
Sesudah & 20 & 80,00 & 4,34 & \\
\hline
\end{tabular}

Tabel 1 menunjukan bahwa terjadi peningkatan pemahaman masyarakat sasaran mengenai hukum dan kewriausahaan. Hal tersebut dapat dilihat dari tingkat signifikansi sebesar 0,008 jauh dibawah 0,05, dan dari rata-rata (mean) hasil jawaban peserta sebelum dan sesudah kegiatan menunjukan adanya peningkatan sebesar 35,00 poin $(80,00-45,00)$. 


\section{KESIMPULAN DAN SARAN}

\section{Kesimpulan}

Kegiatan-kegiatan yang telah dilaksanakan diantara nya adalah Tes Pra Kegiatan, dimana hasilnya menunjukan bahwa pengetahuan Narapidana yang menjadi Mitra PKM-S mengenai Pendidikan Hukum dan Kewirausahaan masih rendah. Hal tersebut dapat dilihat dari skor rata-rata hasil Tes Pra Kegiatan yang diperoleh adalah sebesar 45.

Sementara itu kegiatan pelatihan Soft Skill Pendidikan Hukum dan Kewirausahaan telah dilaksanakan. Situasi kondisi selama kegiatan ini berlangsung diikuti oleh peserta dengan antusias, dibuktikan dengan komunikatif nya mereka selama kegiatan berlangsung. Mereka berkomunikasi dengan pemateri dari Tim PKM-S mengenai hal-hal apa saja yang mereka perlu tanyakan, baik seputar materi yang diberikan, ataupun hal lainnya yang dianggap penting bagi mereka.

Hasil Tes Pasca Kegiatan menunjukan adanya peningkatan pengetahuan Narapidana, yang dibuktikan dengan skor rata-rata yang diperoleh adalah sebesar 80. Tingginya antusiasme Narapidana yang menjadi Mitra PKM-S menunjukan bahwa mereka sangat menginginkan adanya berbagai kegiatan yang mungkin sangat mereka butuhkan, baik selama menjalani masa hukuman ataupun akan menjadi bekal keahlian pada saat mereka bebas dari penjara. Maka saran yang kami berikan bagi Lapas Ciamis adalah perbanyak kegiatankegiatan yang sifatnya adalah untuk memberi bekal keahlian yang dibutuhkan Nrapidana setelah bebas dari penajara.

\section{Saran}

Kegiatan-kegiatan tersebut dapat dilakukan dengan bekerjasama dengan berbagai perguruan tinggi, instansi pemerintah lainnya, dan swasta. Bagi Universitas Galuh, bentuk kerjasama dalam bidang pengabdian kepada masyarakat dengan Lapas Ciamis sangat mungkin dilakukan untuk keberlanjutan program-program di Lapas Ciamis. Karena Universitas Galuh merupakan lembaga pendidikan yang melaksanakan fungsi tridharma perguruan tinggi melalui dosen dan mahasiswa.

\section{UCAPAN TERIMA KASIH}

Ucapan terima kasih secara umum ditujukan kepada pihak-pihak yang telah membantu terselesaikannya kegiatan PKM-S ini baik dari segi dukungan dana, moril, tenaga dan sumbangan pemikiran. Secara khusus kami ucapkan terima kasih kepada Kemenristekdikti atas dana hibah yang telah diberikan untuk mendukung kegiatan-kegiatan Tri Dharma yang 
dilakukan oleh dosen di lingkungan Universitas Galuh, termasuk kegiatan PKM-S ini. Selanjutnya kami pun mengucapkan banyak terima kasih kepada pihak Lapas Kelas II B Ciamis atas kerjasamanya, sehingga kegiatan ini dapat berjalan sesuai dengan yang diharapkan.

\section{DAFTAR PUSTAKA}

Bastaman, H.D. (2007). Logoterapi: Psikologi Untuk Menemukan Makna Hidup dan Meraih Hidup Bermakna. Jakarta: Raja Grafindo Persada.

Lubis, S.M., \& Maslihah, S. (2012). Analisis Sumber-Sumber Kebermaknaan Hidup Narapidana yang Menjalani Hukuman Seumur Hidup. Jurnal Psikologi UPI Bandung, 11(1), 1 April 2012.

Republik Indonesia, 2003, Undang-undang Sistem Pendidikan Nasional No. 20 Tahun 2003.

Purnianti. (2004). Mencari Sebab Pelarian Narapidana Anak. Jurnal Kriminologi Indonesia, 3(3), September 2004. 